May 2006

\title{
Mixed germ cell sex cord-stromal tumors of the testis and ovary. Morphological, immunohistochemical, and molecular genetic study of seven cases
}

\author{
Michal Michal \\ Charles University Hospital and Medical Faculty Hospital, Pilsen, Czech Republic \\ Tomas Vanacek \\ Charles University Hospital, Pilsen, Czech Republic

\section{Radek Sima} \\ Charles University Hospital, Pilsen, Czech Republic \\ Follow this and additional works at: https://jdc.jefferson.edu/pacbfp \\ Dotr Mukensnabl

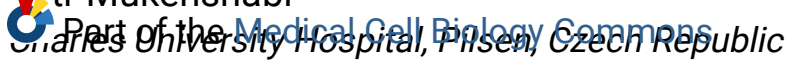 \\ Let us know how access to this document benefits you
}

Charles University Hospital, Pilsen, Czech Republic

\section{Recommended Citation}

Michal, Michal; Vanacek, Tomas; Sima, Radek; Mukensnabl, Petr; Hes, Ondrej; Kazakov, Dmitry

V.; Matoska, Jozef; Zuntova, Anna; Dvorak, Vladimir; and Talerman, Alexander, "Mixed germ cell

sex cord-stromal tumors of the testis and ovary. Morphological, immunohistochemical, and molecular genetic study of seven cases" (2006). Department of Pathology, Anatomy, and Cell Biology Faculty Papers. Paper 16.

https://jdc.jefferson.edu/pacbfp/16

This Article is brought to you for free and open access by the Jefferson Digital Commons. The Jefferson Digital Commons is a service of Thomas Jefferson University's Center for Teaching and Learning (CTL). The Commons is a showcase for Jefferson books and journals, peer-reviewed scholarly publications, unique historical collections from the University archives, and teaching tools. The Jefferson Digital Commons allows researchers and interested readers anywhere in the world to learn about and keep up to date with Jefferson scholarship. This article has been accepted for inclusion in Department of Pathology, Anatomy, and Cell Biology Faculty Papers by an authorized administrator of the Jefferson Digital Commons. For more information, please contact: JeffersonDigitalCommons@jefferson.edu. 


\section{Authors}

Michal Michal, Tomas Vanacek, Radek Sima, Petr Mukensnabl, Ondrej Hes, Dmitry V. Kazakov, Jozef Matoska, Anna Zuntova, Vladimir Dvorak, and Alexander Talerman 


\title{
Mixed germ cell sex cord-stromal tumors of the testis and ovary. Morphological, immunohistochemical, and molecular genetic study of seven cases
}

\author{
Michal Michal, Tomas Vanecek, Radek Sima, Petr Mukensnabl, Ondrej Hes, Dmitry V. \\ Kazakov, Jozef Matoska, Anna Zuntova, Vladimir Dvorak, Alexander Talerman \\ M. Michal, T. Vanecek, R. Sima, P. Mukensnabl, 0. Hes, D. V. Kazakov \\ Sikl's Department of Pathology \\ Charles University Hospital \\ Pilsen, Czech Republic \\ J. Matoska \\ Department of Pathology \\ St. Elizabeth Oncology Institute \\ Bratislava, Slovakia
}

\author{
A. Zuntova \\ Department of Pathology and Molecular Medicine \\ 2nd Medical Faculty \\ Charles University \\ Prague, Czech Republic \\ V. Dvorak \\ Ob/gyn Clinic \\ Brno, Czech Republic
}

\begin{abstract}
A. Talerman
Department of Surgical Pathology

Thomas Jefferson University Hospital

Philadelphia, PA, USA
\end{abstract}

M. Michal (corresponding author)

Sikl's Department of Pathology

Laboratore Spec. Diagnostiky, Medical Faculty Hospital

Alej Svobody 80

30460 PILSEN, Czech Republic

Tel.: +420-603886633

Fax: +420-37-7104650

e-mail: michal@medima.cz

\begin{abstract}
We present the morphological, immunohistochemical, and molecular genetic features of three cases of testicular and four cases of ovarian mixed germ cell sex cord-stromal tumors (MGSCT). The germ cells in the testicular MGSCTs morphologically differed from those in classical seminomas by lacking the typical "square off" quality of the nuclei. In contrast to the nuclei in classical seminomas, their size in testicular MGSCTs was smaller and nucleoli were inconspicuous and the cytoplasm was Periodic Acid-Schiff(PAS)

This is the author's final version of the article, prior to publication in Virchows Arch (2006) 448: 612-622.

C) Springer-Verlag 2006. The published version is available at http://dx.doi.org/10.1007/s00428-006-0155-z, or via www.springerlink.com.
\end{abstract}


negative. Quite on the contrary, the variability in the size of the nuclei of the germ cells in the testicular MGSCTs was more similar to that seen in the germ cells of spermatocytic seminomas. Immunohistochemically, the germ cells of MGSCTs in one case reacted positively with antibody to AE1-AE3 by paranuclear dotlike or rodlike positivity. All three testicular MGSCTs had a negative reaction with the rest of antibodies, including placental alkaline phosphatase (PLAP), OCT4, and c-kit protein. Ovarian MGSCT in our series differed from the testicular lesions in both the germ cell component and the sex cord component. The germ cells in all four ovarian cases had cytomorphological and immuno-histochemical features identical to those in classical seminomas/dysgerminomas. They possessed the typical "square off" quality of the nuclei, which were much more blastic, with more mitoses compared with the testicular tumors in our series, and they were PLAP (4/4), OCT4 (4/4) and c-kit protein (3/4) positive immunohistochemically. The cytoplasm of the germ cells in ovarian neoplasms contained PAS positive glycogen. Germ cells in one ovarian MGSCTs showed amplification of $12 \mathrm{p}$. All other germ cells were negative for amplification of 12p. All five successfully analyzed cases showed no mutation in all studied exons and exon-intron junctions in c-kit and PDFGRA genes.

\section{Introduction}

A distinctive gonadal neoplasm composed of germ cells associated with sex cord stroma derivatives has been described and designated as "Pflügerome" $[5,21]$ or mixed germ cell sex cord-stromal tumor (MGSCT) $[33,34]$. Most cases of MGSCT were described in the ovaries [1, 14, 19, 27, 32, 33, 35, 37, 38, 41, 47]; however, there were also a few cases of MGSCT reported in the testis $[3,8,28]$. Yet the existence of these tumors in the testis had recently been questioned by a group of authors, who considered these lesions to represent sex cord-stromal tumors with entrapped germ cells rather than genuine MGSCT $[43,46]$. We present morphological features, as well as immunohistochemical and molecular genetic findings in three testicular and four ovarian cases of MGSCT. One case of testicular MGSCT [23] and two cases of ovarian MGSCT [1, 47] included in our series have been published previously.

\section{Materials and methods}

Tissues from three cases of testicular and four cases of ovarian MGSCT were available. In one testicular case, only a limited amount of unstained reserve slides was available. In one testicular case, practically the entire tumor was sampled and its tissue was histologically processed. Two cases were seen in consultation by one of the authors (AT), two cases were seen in consultation by another author (MM), two cases were contributed by two other authors of the study (JM and AZ), and tissue from one case was contributed by generosity of Dr. J. Arroyo. Tissues were fixed in $4 \%$ formaldehyde and embedded in paraffin using routine procedures. Five-micrometer thick sections were cut from the tissue blocks and stained with routine staining methods.

This is the author's final version of the article, prior to publication in Virchows Arch (2006) 448: 612-622.

C) Springer-Verlag 2006. The published version is available at http://dx.doi.org/10.1007/s00428-006-0155-z, or via www.springerlink.com. 


\section{Immunohistochemistry}

For immunohistochemical investigations, the following primary antibodies were used: MIB1 (MIB1, 1:1,000, NeoMarkers, Fremont, CA, USA), c-kit protein (polyclonal, 1:100, DakoCytomation, Glostrup, Denmark), CD3O (Ber-H2: DakoCytomation), Inhibin (Ri, Serotec, Düsseldorf, Germany), cytokeratins (AE 1 /AE3, 1:1,000, Boehringer), low molecular weight cytokeratin (CAM 5.2, 1:50. Becton Dickinson. San Jose. CA. USA). placental alkaline phosphatase (polyclonal: DakoCytomation), $\alpha$ smooth muscle actin (1A4; DakoCytomation), neuron specific enolase (polyclonal; DakoCytomation), and EMA (E29, DakoCytomation). A polyclonal primary goat- antiOCT4 antibody (Santa Cruz, CA, USA) raised against the - $\mathrm{COOH}$ terminus of the protein was used.

Microwave pretreatment of the tissue sections was used before applying of the primary antibodies. The primary antibodies were visualized using the anti-goat antibody labeled with peroxidase (Santa Cruz, CA) for the antiOCT4 antibody and supersensitive streptavidin-biotin-peroxidase complex (BioGenex, San Ramon, CA, USA) for all the rest of the primary antibodies. Appropriate positive and negative control slides were employed.

\section{Molecular genetics and cytogenetics}

\section{DNA extraction}

DNA was extracted from formalin-fixed, paraffin-embedded tissues. Several 5- $\mu \mathrm{m}$ thick sections were placed on the slides. Hematoxylin eosin stained slides were examined for determination of area of tumor tissue. Then, tumor tissue from unstained slides was scraped, and DNA was isolated by the DNeasy Tissue Kit (QIAgen, Hilden, Germany) according to the manufacturer's protocol. In several cases where quality or amount of extracted DNA was low, concentration with Microcon 100 (Millipore, Billerica, MA, USA) according to the manufacturer's protocol was carried out.

Mutation status of the exons 9, 11, 13, and 17 of the c-kit gene (accession number U63834) and exons 12 and 18 of PDGFRA gene (accession number D5001 7) by PCR and direct sequencing

PCR was carried out using primers shown in Table 1. The reaction conditions were as follows: $12.5 \mu 1$ of HotStart Taq PCR Master Mix (QiAgen), 10 pmol of each primer, $100 \mathrm{ng}$ of template DNA and distilled water up to $25 \mu 1$. The amplification program consisted of denaturation at $95^{\circ} \mathrm{C}$ for $15 \mathrm{~min}$ and then 40 cycles of denaturation at $95^{\circ} \mathrm{C}$ for $1 \mathrm{~min}$, annealing at $54^{\circ} \mathrm{C}$ for $1 \mathrm{~min}$, and an extension at $72^{\circ} \mathrm{C}$ for $1.5 \mathrm{~min}$ for all amplicons. The program was finished by $72^{\circ} \mathrm{C}$ incubation for $7 \mathrm{~min}$.

This is the author's final version of the article, prior to publication in Virchows Arch (2006) 448: 612-622.

(C) Springer-Verlag 2006. The published version is available at http://dx.doi.org/10.1007/s00428-006-0155-z, or via www.springerlink.com. 
Successfully amplified PCR products were purified with a QIAquick spin PCR purification kit (QIAgen), side sequenced using a Big Dye Terminator Sequencing kit (PE/ Applied Biosystems, Foster City, CA, USA) and run on an automated sequencer ABI Prism 310 (PE/Applied Biosystems) at a constant voltage of $11.3 \mathrm{kV}$ for $20 \mathrm{~min}$.

Tissue pretreatment and fluorescence in situ hybridization using CEP 12 and $12 p$ probes

From each specimen, 4- $\mu \mathrm{m}$ thick sections were placed onto positively charged slide. Hematoxylin and eosin stained slides were examined for determination of areas for cell counting. The unstained slides were routinely deparaffinized and treated by a $30 \%$ sodium bisulfite for $30 \mathrm{~min}$ at $42^{\circ} \mathrm{C}$. Then, the slides were washed twice in $2 \times$ sodium salt citrate $(2 \times \mathrm{SSC})$ and immersed into digestion solution consisting of $2 \times \mathrm{SSC} /$ proteinase $\mathrm{K}(0.25 \mathrm{mg} / \mathrm{ml})$ for 30 to $60 \mathrm{~min}$ at $42^{\circ} \mathrm{C}$. The slides were then placed into distilled water for $2 \mathrm{~min}$, dehydrated in a series of ethanol solution, and air-dried. Probes for 12p Spectrum Green, CEP 12 Spectrum Orange (factory premixed) and LSI/WCP hybridization buffer (VYSIS/Abbott, IL, USA) were mixed in a 1:2:7 ratio. An amount of $10 \mu \mathrm{l}$ of probe mix was applied on specimens and co-denatured simultaneously at $85^{\circ} \mathrm{C}$ for $10 \mathrm{~min}$. After hybridization overnight in a humidified chamber at $37^{\circ} \mathrm{C}$, the slides were washed for $2 \mathrm{~min}$ in washing buffer consisting of $0.4 \times \mathrm{SSC} / 0.3 \% \mathrm{NP}-40$ at $73^{\circ} \mathrm{C}$ and then in buffer consisting of $2 \times \mathrm{SSC} / 0.1 \% \mathrm{NP}-40$ at room temperature. The slides were airdried in the dark, counterstained with 4',6-diamidino-2-phenylindole-2HCl (DAPI) in an antifade medium, and immediately examined.

\section{FISH interpretation}

The sections were examined with an Olympus BX6O fluorescence microscope using a 100× objective and filter sets Triple Band Pass [DAPI/fluorescein isothiocyanate (FITC)/Texas Red) and Dual Band Pass (FITC/Texas Red). Scoring of amplification was performed by counting the ratio of the number of both fluorescent signals (12p: CEP12) in 60 randomly selected nonoverlapping tumor cell nuclei. Each slide was independently enumerated by two observers (TV and RS). Tumors with a ratio of signals $<1.5$ as a mean per nucleus were interpreted as non-amplified, whereas cases exhibiting a ratio of signals $\geq 1.5$ as a mean were classified as amplified ones [17]. In all cases, counting of germ cell nuclei population was performed.

\section{Results}

\section{Case histories}

Case 1

This is the author's final version of the article, prior to publication in Virchows Arch (2006) 448: 612-622.

C) Springer-Verlag 2006. The published version is available at http://dx.doi.org/10.1007/s00428-006-0155-z, or via www.springerlink.com. 
A 35-year-old phenotypically normal man with karyotype 46XY presented with a gradually enlarging, asymptomatic left testicular mass that had been present for 25 years. Otherwise, the affected testis was elastic and painless, and the contralateral testis had normal size and consistency; both testes were normally descended. No enlarged lymph nodes or metastases were revealed by ultrasonography and computed tomography. Serum levels of $\alpha$-fetoprotein, $\beta$-human chorionic gonadotropin (HCG), and carcinoembryonic antigen were within the normal range. A left orchiectomy was performed. Grossly, the parenchyma of involved testis was replaced by a uniform whitish soft tissue; no involvement of testicular adnexa and tunica albuginea was noted. The tumor was roundshaped, well- circumscribed, white in color, and measured $4 \times 5 \times 5 \mathrm{~cm}$. The unaffected testicular tissue was compressed by the tumor. No adjuvant chemotherapy and radiotherapy was given or administered. The patient is free of disease 11 years after the surgical excision.

\section{Case 2}

A normally developed 41-year-old man consulted an urologist because of urinary frequency that was attributed to the cystitis. He also noticed a slowly progressive, painless enlargement of the right testis during the last 4 years, which was unrelated to his current complaint. The urologic examination disclosed a right-sided testicular tumor that was solid and firm. The left testis was normal. Both testes were normally descended. Relevant laboratory and radiological investigations, including serum $\alpha$-fetoprotein and HCG determinations, showed no abnormalities. Two years after the right radical orchiectomy, the patient was well without any evidence of recurrence or metastases.

\section{Case 3}

A 27-year-old man presented with complaints of pain in the right scrotum. Clinical examination revealed a testicular mass. Orchiectomy was performed. The affected testis measured $7 \times 4 \mathrm{~cm}$ and was replaced by a well-circumscribed tumor, two-thirds of which exhibited a cystic change. There were no signs of necrosis or hemorrhage. The follow-up of the patient is not available.

\section{Case 4}

The patient, a 30-year-old woman, nullipara and nulligravida with normal karyotype (46XX) was admitted for treatment because of a persistent pelvic pain. Examination revealed a right adnexal mass $7 \times 4-\mathrm{cm}$ in size. There was no evidence of residual tumor in the pelvis at operation. The postoperative recovery was uneventful. Sixty-seven months later, a large, palpable pelvic mass was found above the uterine fundus. At laparotomy, a 7-cm tumor adherent to the serosa of the uterus was identified and surgically removed. Postoperatively, the patient was further treated with chemotherapy (bleomycin, cisplatin,

This is the author's final version of the article, prior to publication in Virchows Arch (2006) 448: 612-622.

C) Springer-Verlag 2006. The published version is available at http://dx.doi.org/10.1007/s00428-006-0155-z, or via www.springerlink.com. 
and etoposide) with an excellent response. She was clinically free of disease 10 months later.

\section{Case 5}

A 4-year-old girl presented with symptoms of precocious isosexual pseudopuberty, including mammary enlargement. The gynecological examination revealed an infantile uterus and a left adnexal mass. The vulva was slightly swollen and no pubic hair could be demonstrated. The vaginal cytology revealed estrogenic stimulation. The serum levels of somatotropin, luteinizing hormone, $\alpha$-fetoprotein, prolactin, and $\beta$-HCG were within normal limits. The karyotype of the patient was $46 \mathrm{XX}$ and her sex chromatin was normal. She was treated with a right oophorectomy. A bosselated, irregular, $8 \times 4 \times 4-\mathrm{cm}$ mass was found in the right ovary. The patient subsequently received radiotherapy (total dose 40 Gy applied during 4 weeks) and chemotherapy (5-fluorouracil, actinomycin D, and cyclophosphamide). After surgery, the vaginal cytology returned to normal in 2 months. Her breast enlargement regressed slowly to the normal size 1 year after the operation. Thirteen years after the oophorectomy, the patient achieved normal puberty and there was no evidence of recurrence or metastasis.

\section{Case 6}

A 39-year-old woman presented with a round-shaped tumor mass in the left ovary measuring $9 \mathrm{~cm}$ in diameter. The patient suffered from ascites. She underwent a bilateral ovariectomy. The contralateral ovary proved to be normal both grossly and histologically. The karyotype of the patient was 46XX. Seven years after the ovariectomy, the patient is well and free of disease.

\section{Case 7}

An 11-year-old girl was noted to have precocious pseudopuberty and was found to have an ovarian tumor affecting the right ovary and measuring $6 \times 4 \times 3 \mathrm{~cm}$. The left ovary was normal. The karyotype of the patient was 46XX. After the operation there was regression of the pseudo-puberty symptoms. She achieved normal puberty and was followed for 6 years without any evidence of recurrent disease.

\section{Histology}

Histologically, all seven cases of MGSCT revealed two components: germ cells and sex cord stromal component (SCC). No evidence of other type of germ cell tumors such as seminomaldysgerminoma, embryonal carcinoma, yolk sac tumor, or teratoma [37, 44] and no sarcomatous differentiation, as described in spermatocytic seminomas $[8,11,24$, 42], were seen in our cases of MGSCT. Neither HCG secreting multinucleated cells, as seen in $5 \%$ of dysgerminomas and in seminomas, nor calcifications were present in our

This is the author's final version of the article, prior to publication in Virchows Arch (2006) 448: 612-622.

(C) Springer-Verlag 2006. The published version is available at http://dx.doi.org/10.1007/s00428-006-0155-z, or via www.springerlink.com. 
cases. Because histology of the germ cells, stromal SCC, and immunohistochemical findings of testicular and ovarian tumors differed they will be described separately.

Testicular tumors All three testicular MGSCTs had a similar histological appearance. The tumors showed germ cells arranged in groups or as solitary units within the background of dense, diffuse proliferations of spindle- shaped sex cord stromal cells. Within a tumor, there were areas where the SCC predominated (Fig. 1), as well as areas where the dominant cells were the germ cells (Fig. 2). The germ cells were characterized by an abundant clear cytoplasm and a variably blastic nucleus with a fine chromatin, having one to several inconspicuous nucleoli. No areas, in which the germ cells resembled entrapped cells within testicular tubules or within a sex cord stromal tumor were observed in any of the reviewed slides. At low magnification, it was apparent that the germ cells formed an integral part of the neoplasm (Fig. 3). The germ cells often demonstrated variation in the size of their nuclei, and these ranged from small, deeply basophilic to large blastic ones (Fig. 2). In Cases I and 3, they revealed mitoses including atypical ones (Fig. 4). A copious amount of the cytoplasm and relatively smaller nuclei of the germ cell often rendered the germ cell a targetoid appearance (Fig. 5). The germ cells in the testicular MGSCTs morphologically differed from those in classical seminomas by lacking the typical "square off" quality of the nuclei. In contrast to the nuclei in classical seminomas, their size in testicular MGSCTs was smaller and nucleoli were inconspicuous. In addition, Periodic Acid-Schiff (PAS) revealed no glycogen in the cytoplasm of MGSCTs. SCC was composed of spindle cells with nuclei having longitudinal clefts and inconspicuous nucleoli (Fig. 5). Focally, SCC formed peripheral palisading. In many areas, the tumor cells were intermixed with dense collagen (Fig. 6). Rarely, the collagenous extracellular matrix formed Call-Exner-like bodies. Leydig-like and lutein cells and concentric calcifications typical of gonadoblastoma were lacking. Immunohistochemically, the germ cells of MGSCTs in Case 1 reacted positively with antibody to AE 1-AE3 (Boehringer: Mannheim) by paranuclear dot-like or rod-like positivity (Fig. 7). The germ cells in the other two cases of testicular MGSCTs were AE1-AE3 negative. All three testicular MGSCTs were negative with the rest of antibodies, including placental alkaline phosphatase (PLAP), OCT4, and c-kit protein. MIB1 antibody stained almost exclusively the germ cell component, and in Case 1, as many as $40 \%$ of all germ cells stained with the MIB 1 antibody (Fig. 8), while the SCC revealed only very rare MIB 1 positive cells (less than 1\%). Inhibin stained the cells of SCC (Fig. 9). Actin antibody stained only capillary pericytes (Table 2).

Ovarian tumors Ovarian tumors in our series differed from the testicular lesions in both the germ cell component and the SCC. The germ cells in all four ovarian cases had cytomorphological features identical to those present in classical seminomas/ dysgerminomas. They possessed the typical "square off" quality of the nuclei (Fig. 10), which were much more blastic with more mitoses compared with the testicular tumors in our series. The cytoplasm of the germ cells in ovarian neoplasms contained PAS positive glycogen. SCC differed from case to case. In Case 4, it formed lobules composed of cells

This is the author's final version of the article, prior to publication in Virchows Arch (2006) 448: 612-622.

C) Springer-Verlag 2006. The published version is available at http://dx.doi.org/10.1007/s00428-006-0155-z, or via www.springerlink.com. 
with clear to eosinophilic cytoplasm forming either hollow microfollicles inside the lobules or microfollicles filled with collagen. These features, along with a peripheral palisading of the lobules (Fig. 11), imparted to the tumors an appearance somewhat similar to the sex cord tumors with annular tubules [45] (Fig. 12). In Cases 6 and 7, the SCC formed less well-defined lobules with greater amount of fibrous septa dividing them. In Case 6, the sex cord stromal cells focally differentiated into a columnar glandular epithelium with a ciliated brush border (Fig. 13). The SCC in Case 5 differed from the other three ovarian cases in that it formed trabeculae with stromal cells lying perpendicular to the long axis of the trabeculae (Fig. 14). The germ cells and SCC formed sharply circumscribed lobules (Fig. 15). In no case in our series did the germ cells grow outside the confines bordered by the SCC. There were no Leydig-like cells, lutein cells, or concentric calcifications typical of gonadoblastoma whatsoever.

Immunohistochemically, the germ cells in all four ovarian tumors stained positively with the antibodies to neuron specific enolase (NSE), PLAP (Fig. 15), OCT4 and, with the exception of Case 7, they reacted positively for the c-kit protein antibody. Rare germ cells in Case 5 stained positively with the antibody to cytokeratins AE1-AE3; otherwise, the germ cells in all cases were negative with all the rest of the antibodies. SCC was immunohistochemically positive with inhibin antibody in all four cases (in Case 5 only focally) and with cytokeratin AE1-AE3 antibody in three out of four cases. It was negative with the rest of the antibodies. The MIB1 antibody reacted in 20-30\% of the germ cells, and only very rare cells of the SCC (less than $1 \%$ in all four cases) were positive with this antibody (Table 2).

\section{Molecular genetic findings}

Of the seven cases studied, mutation status of c-kit and PDGFRA genes was successfully analyzed in five cases (Cases 1, 2, 4, 5, and 7). In Case 6, no amplifiable DNA was presented probably due to wrong fixation. In Case 3, no tissue was at hand for molecular genetic study. All successfully analyzed cases showed no mutation in all studied exons and exon-intron junctions.

\section{Molecular cytogenetics finding}

Of the seven studied cases, FISH was successfully performed in four cases $(1,4,5$, and 7). In Cases 2 and 6, no signals of 12p and CEP 12 probe were visible after repeated FISH analysis. In Case 3, no tissue was at hand for molecular cytogenetic study. Of all successfully analyzed cases, only Case 7 showed amplification of 12p (Fig. 16). All others were negative for amplification of $12 \mathrm{p}$. Results of FISH are summarized in Table 3.

This is the author's final version of the article, prior to publication in Virchows Arch (2006) 448: 612-622.

(C) Springer-Verlag 2006. The published version is available at http://dx.doi.org/10.1007/s00428-006-0155-z, or via www.springerlink.com. 


\section{Discussion}

MGSCTs occur in the gonads of phenotypically and genetically normal subjects. They were first described by Masson as a Pflügerome in 1912 [21] and later as "epitheliomas pflugeriens" in 1923 [22]. Later, there were several cases published in the ovaries [1, 14, $19,27,32,33,35,37,38,41,47]$ and occasional cases in the testes [3, 28, 36, 37].

However, the existence of these tumors in the testis has recently been questioned by a group of authors who reviewed nine testicular sex cord-stromal tumors containing germ cells, which closely mimicked MGSCT but differed from the latter, in that the germ cells were entrapped and nonneoplastic rather than neoplastic $[43,461$. They thought that these tumors closely resembled MGSCT, but represented sex cord stromal tumors with entrapped germ cells, which they considered were nonneoplastic. The evidence presented to support this view was that the germ cells were distributed peripherally and were associated with entrapped seminiferous tubules. They were also said to occur in clusters with vaguely tubular shapes, consistent with preexisting seminiferous tubules. Although some of these cases may have represented sex cord-stromal tumors with entrapped germ cells, germ cells seemed not to have any relation to preexistent seminiferous tubules in some of them and were scattered haphazardly forming true predominant part of the lesion, while in other parts of the sex cord elements predominated. The germ cells showed variable appearances. In one of those cases, inhibin stain showed an association of the germ cells with nonneoplastic Sertoli cells. The germ cells in their cases lacked large, vesicular nuclei with prominent nucleoli, closely resembling type A spermatogonia [43].

Our testicular cases differed from the cases of Ulbright et al. [43]. Our tumors were composed of germ cells with vesicular nuclei and spindle-shaped sex cord-stromal cells. No association whatsoever was found, even on intentional search, between the germ cells and preexisting seminiferous tubules in any of the 20 sampled blocks of Case 1, nor was this feature observed in multiple sections in Cases 2 and 3. Furthermore, in most of the slides, the germ cells formed a predominant part of the microscopic fields. In addition, the size of the germ cells varied, ranging from cells with small hyperchromatic nuclei to large blastic cells with vesicular nuclei. In that respect, the nuclear variations in the germ cell component in our case had some similarities to nuclear variations seen in spermatocytic seminomas [30]. Atypical mitoses in germ cells present in two of the three testicular cases are another argument supporting their neoplastic nature. Immunonegativity with the antibodies to PLAP, NSE, c-kit protein, and OCT4 [6, 12] and the absence of cytoplasmic glycogen within the germ cells in our testicular cases do not necessarily preclude their nonneoplastic nature, because germ cells in spermatocytic seminomas, in our experience, lack cytoplasmic glycogen and they are consistently negative with all these antibodies as well. Positivity with the anticytokeratin antibody AE1-AE3 in one testicular and one ovarian MGSCT is an interesting and hitherto unreported feature of MGSCT. Cytokeratin immunoreactivity, including AE1-AE3, has been repeatedly described in classical seminomas [7, 10]. Cheville et al. [71 for example

This is the author's final version of the article, prior to publication in Virchows Arch (2006) 448: 612-622.

(C) Springer-Verlag 2006. The published version is available at http://dx.doi.org/10.1007/s00428-006-0155-z, or via www.springerlink.com. 
showed that $36 \%$ of classical seminomas reacted with this antibody. Occasional cytokeratin positivity in spermatocytic seminomas was described as well [8]. However, no such cytokeratin immunoreactivity can be seen in germ cells of the normal testes.

When judging the figures of other published cases of testicular MGSCT [3, 28], it seems that they were morphologically very similar to our cases. Typical for testicular MGSCTs in our series and those in the literature $[3,28]$ is the SCC composed of spindle-shaped cells incorporating clusters of germ cells with a copious cytoplasm rendering them a targetoid appearance. In contrast, the SCC and germ cells of the ovarian MGSCTs differed from testicular MGSCTs. The SCC either formed trabeculae with perpendicularly arranged sex cord stromal cells or it formed lobules or tubules with peripheral palisading. A clear to eosinophilic and homogeneous cytoplasm of these sex cord stromal cells imparted a vague similarity of sex cord tumor with annular tubules to one ovarian MGSCT in our series [45]. Besides the patterns of SCC seen in our cases, several other patterns were described in the literature in the ovaries including a retiform tubular pattern [41], a pattern forming hollow tubules [19], and others [14, 37].

Moreover, germ cells in ovarian MGSCTs had a "square off" appearance [44] of classical seminomas/dysgerminomas. They contained PAS positive diastase sensitive glycogen in their cytoplasm and further they lacked the targetoid appearance of germ cells in the testicular MGSCTs. Immunohistochemistry revealed additional differences between the germ cells in the testicular and ovarian MGSCTs, inferring their different nature. The ovarian MGSCTs were PLAP, OCT4, and NSE positive, while no positivity with these markers was found in the testicular neoplasms. All four ovarian tumors were immunohistochemically c-kit protein positive. All these markers are typically positive in classical seminomas/ dysgerminomas $[2,40]$.

KIT protein is expressed in most cases of classical seminomas/dysgerminomas, both in gonadal [40] and extragonadal location [25], while it is negative in nonseminomatous germ cell tumors. We have not found KJT protein expression in any of the 14 cases of spermatocytic seminomas in our files. To date there have been several reports of Kit mutations found in exon 17 in germ cell tumors. Tian et al. found c-kit exon 17 mutations in 2/23 cases of the gonadal [391 seminomas/dysgerminomas. Przygodzki et al. [26] found it in 3/17 cases of mediastinal seminomas with mutations and Kemmer et al. [161 found exon 17 of $c$-kit gene mutations in 14/54 cases of gonadal seminomas/ dysgerminomas. Pauls et al. [25] described a case of primary retroperitoneal seminoma with a point mutation in codon 557 of exon 11 of $c$-kit gene. No mutations were found in this case in exon 17. We searched for activation mutations in exon 9,11,13, and 17 of $c$ kit gene and exon 12 and 18 of the PDGFRA gene, which are mutations often found in gastrointestinal stromal tumors [9]. While $75 \%$ of ovarian cases expressed KIT protein at immunohistochemical level, we found no activating mutations on any exons of c-kit and PDGFRA genes in any of MGSCTs in our series.

This is the author's final version of the article, prior to publication in Virchows Arch (2006) 448: 612-622.

C) Springer-Verlag 2006. The published version is available at http://dx.doi.org/10.1007/s00428-006-0155-z, or via www.springerlink.com. 
Another point supporting the similarity of germ cells in the ovarian MGSCTs to germ cells in dysgerminomas is the fact that several cases of ovarian MGSCTs progressed into invasive dysgerminoma [13, 18, 19, 37]. In four children, there is a described malignant overgrowth by other malignant germ cell elements, including choriocarcinoma and yolk sac tumor [18]. In three of these patients, the tumor metastasized and resulted in the deaths of the patients [18]. No such events have ever been described in testicular MGSCTs.

The finding of excess genetic material of the short arm of chromosome 12 in one of our two ovarian MGSCTs is of great interest. This genetic abnormality occurs in all primary sites and histologic types of all human germ cells tumors [4, 17,201 with the exception of spermatocytic seminomas and prepubertal teratomas of the testis. Data suggest that the consistent gain of genetic material from chromosome 12 may be crucial for the development of an invasive germ cell tumor [29]. Overrepresentation of $12 p$ renders the tumor cells independent from the supporting Sertoli cells. Cells of intratubular germ cell neoplasia therefore lack overrepresentation of $12 p$ [20]. The presence of gain in the short arm of chromosome 12 in our case 7 is in accordance with the well-documented ability of ovarian MGSCTs to produce invasive dysgerminoma and other neoplastic germ cell components $[13,18,19,37]$. The longer follow-up and more cases would be necessary to find out whether this genetic event in ovarian MGSCTs has a prognostic significance in relation to development of an invasive component.

In contrast to the ovarian MGSCTs, germ cells in all three cases of testicular MGSCTs in our series lacked cytoplasmic glycogen and immunohistochemical positivity with PLAP, OCT4, and c-kit protein. Interestingly, in our experience and that of others [8], all these markers, including OCT4 $[15,44]$ are absent in spermatocytic seminomas. MIB1 immunoreactivity revealed that the germ cells are a quickly proliferating component of the neoplasms, while the sex cord stromal cells represent a relatively slowly proliferating part of the tumors. This militates against the suggestion that germ cells in the testicular MGSCTs represent nonneoplastic, possibly entrapped germ cells [43, 46].

Another interesting feature of the tumors was the relation of the sex cord stromal cells and the germ cells. In no case in our series did the germ cells grow outside the confines bordered by the SCC. It looked as though the sex cord stromal cells of the tumors possessed a homing phenomenon to the germ cells. In the differential diagnosis, MGSCT should be distinguished especially from gonadoblastoma [31]. In contrast to our cases, all of which had normal karyotype, the gonadoblastomas nearly always occur in patients with pure or mixed gonadal dysgenesis with an altered karyotype or, in men, pseudohermaphrodites in streak gonad or testis. Leydig-like and lutein cells and concentric calcifications typical of gonadoblastoma were uniformly lacking in our cases. In contrast to gonadoblastomas, there is no evidence of virilization in MGSCTs and, if there are signs of abnormal endocrine activity in MGSCTs, they manifest themselves as

This is the author's final version of the article, prior to publication in Virchows Arch (2006) 448: 612-622.

C) Springer-Verlag 2006. The published version is available at http://dx.doi.org/10.1007/s00428-006-0155-z, or via www.springerlink.com. 
feminization. MGSCTs show also proliferative activity in the sex cord-stromal component, while in gonadoblastoma, proliferative activity is seen in only the germ cells.

The widespread presence of germ cells distinguishes MGSCTs from Sertoli-Leydig cell tumors, especially from those neoplasms showing a retiform component.

In summary, we presented three cases of testicular and four cases of ovarian MGSCTs. The morphology and immunohistochemical profile of testicular and ovarian MGSCTs differed. The immunoprofile of the germ cells in testicular MGSCTs was similar to that observed in spermatocytic seminoma, and the immunoprofile of the germ cells in ovarian lesions was similar to that seen in classical seminoma/dysgerminoma. However, the number of published testicular examples of MGSCTs is too small to generalize that all of them differ from ovarian MGSCTs. It cannot be excluded that, in addition to the testicular MGSCTs in which the germ cells have immunohistochemical properties of the spermatocytic seminomas as in our series, there might exist MGSCTs with immunohistochemical properties of classical seminoma/dysgerminoma indistinguishable from the ovarian examples of MGSCTs.

\section{Acknowledgement}

We would like to thank to Dr. J. Arroyo for allowing us to use a tissue from his case [1] for the study.

\section{References}

1. Arroyo JG, Harris W, Laden A (1998) Recurrent mixed germ cell sex cord stromal tumor of the ovary in an adult. mt j Gynecol Pathol 17:281-283

2. Baker PM, Oliva E (2005) Immunohistochemistry as a tool in the differential diagnosis of ovarian tumors: An update. Int J Gynecol Pathol 24:39-55

3. Bolen JW (1981) Mixed germ cell sex cord stromal tumor. A gonadal tumor distinct from gonadoblastoma. Am J Clin Pathol 75 :565-573

4. Bosl GJ, Ilson DH, Rodriguez E, Motzer RJ, Reuter yE, Chaganti RS (1994) Clinical relevance of the $\mathrm{i}(12 \mathrm{p})$ marker chromosome in germ cell tumors. J Natl Cancer Inst 86:349-355

5. Cabanne F (1971) Gonadoblastomes et tumeurs de l'ebauche gonadique. Ann Anat Pathol (Paris) $16: 387-404$

6. Cheng L (2004) Establishing a germ cell origin for metastatic tumors using OCT4 immunohistochemistry. Cancer 101:2006-2010

7. Cheville JC, Rao S, Iczkowski KA, Lohse CM, Pankratz VS (2000) Cytokeratin expression in seminoma of the human testis. Am J Clin Pathol 113:583-588

8. Cummings OW, Ulbright TM, Eble IN, Roth LM (1994) Spermatocytic seminoma: An immunohistochemical study. Hum Pathol 25:54-59

9. Daum 0, Klecka J, Ferda J, Treska V, Vanecek T, Sima R, Mukensnabl P, Michal M (2005) Gastrointestinal stromal tumor of the pancreas: case report with documentation of kit gene mutation. Virchows Arch 446:470-472

10. Denk H, Moll R, Weybora W, Lackinger E, Vennigerholz F, Beham A, Franke WW (1987) Intermediate filaments and desmosomal plaque proteins in testicular seminomas and

This is the author's final version of the article, prior to publication in Virchows Arch (2006) 448: 612-622.

C) Springer-Verlag 2006. The published version is available at http://dx.doi.org/10.1007/s00428-006-0155-z, or via www.springerlink.com. 
nonseminomatous germ cell tumours as revealed by immunohistochemistry. Virchows Arch A Pathol Anat Histopathol 410:295-307

11. Floyd C, Ayala AG, Logothesis CJ, Silva EG (1988) Spermatocytic seminoma with associated sarcoma of the testis. Cancer 61:409-414

12. Hattab EM, Pang-Hsien T, Wilson DJ, Cheng L (2005) OCT4 immunohistochemistry is superior to placental alkaline phosphatase (PLAP) in the diagnosis of central nervous system germinoma. Am J Surg Pathol 29:368-371

13. Hughesdon PE, Kumarasamy T (1970) Mixed germ cell tumours (gonadoblastomas) in normal and dysgenetic gonads. Case reports and review. Virchows Arch A Pathol Pathol Anat 349:258280

14. Jacobsen GK, Braendstrup 0, Talerman A (1991) Bilateral mixed germ cell sex-cord stroma tumour in a young adult woman. APMIS 23:132-137

15. Jones TD, Ulbright TM, Eble IN, Baldridge LA, Cheng L (2004) OCT4 staining in testicular tumors: a sensitive and specific marker for seminoma and embryonal carcinoma. Am J Surg Pathol 28:935-940

16. Kemmer K, Corless CL, Fletcher JA, McGreevey L, Haley A, Griffith D, Cummings OW, Wait C, Town A, Heinrich M (2004) KIT mutation common in testicular seminomas. Am J Pathol 164:305-313

17. Kemek KM, Brunelli M, Ulbright TM, Eble TN, Martignoni G, Zhang S, Michael H, Cummings OW, Cheng L (2004) Fluorescence in situ hybridization analysis of chromosome 12p in paraffinembedded tissue is useful for establishing germ cell origin of metastatic tumors. Mod Pathol 17:1309-1313

18. Kurman RJ (2002) In: Talerman A (ed) Germ cell tumors of the ovary. Blaustain's Pathology of the Female Genital Tract, 5th edn. Springer, Berlin Heidelberg New York

19. Lacson AG, Gillis DA, Shawwa A (1988) Malignant mixed germ cell sex cord stromal tumors of the ovary associated with isosexual precocious puberty. Cancer 61:2122-2133

20. Looijenga LHJ, Zafarana G, Grygalewicz B, Summersgill B, Debiec-Rychter M, Veltman J, Schoenmakers EFPM, Rodriguez S, Jafer O, Clark J, van Kessel ADG, Shipley J, van Gurp RJHLM, Gillis AJM, Oosterhuis JW (2003) Role of gain of 12p in germ cell tumour development. APMIS 111:161-173

21. Masson P (1912) Pflügerome. Bull Soc Anat Paris 14:403-404

22. Masson P (1923) Les tumeurs. Epitheliomas pflugeriens. In: Diagnostics de Laboratoire. Maloine Editions, Paris, pp 477-478

23. Matoska J, Talerman A (1989) Mixed germ cell-sex cord stroma tumor of the testis. A report with ultrastructural findings. Cancer 64:2146-2153

24. Matoska J, Talerman A (1990) Spermatocytic seminoma associated with rhabdomyosarcoma. Am J Clin Pathol 94:89-95

25. Pauls K, Wardelmann E, Franke FE, Heukamp L, Büttner R, Mey U, Zhou H (2005) Primary extragonadal germ cell tumour: unusual localization of a c-kit mutated retroperitoneal seminoma in the gastric wall. Histopathology 47:11-113

26. Przygodzki RM, Hubbs AE, Zhao FQ, O'Leary TJ (2002) Primary mediastinal seminomas: evidence of single and multiple KIT mutations. Lab Invest 82:1369-1375

27. Reeves G, Elias E, Sarancone S, Albertengo A (2001) Lesiones mixtas de células germinales, cordones sexuales y estroma del ovaria. Patologia 39:116-126

28. Rames RA, Richardson M, Swiger F, Kaczmarek A (1995) Mixed germ cell-sex cord stromal tumor of the testis: the incidental finding of a rare testicular neoplasm. J Urol 154:1479

29. Reuter VE (2005) Origins and molecular biology of testicular germ cell tumors. Mod Pathol 18:S51-S60

30. Rosai J, Silber I, Khodadoust K (1969) Spermatocytic seminoma. I. Clinicopathologic study of six cases and review of the literature. Cancer 24:92-116

31. Scully RE (1970) Gonadoblastoma: a review of 74 cases. Cancer 25:1340-1356

This is the author's final version of the article, prior to publication in Virchows Arch (2006) 448: 612-622.

C) Springer-Verlag 2006. The published version is available at http://dx.doi.org/10.1007/s00428-006-0155-z, or via www.springerlink.com. 
32. Speleman F, Dermaut B, De Potter CR, van Gele M, van Roy N, De Paepe A, Laureys G (1997) Monosomy 22 in a mixed germ cell sex cord-stromal tumor of the ovary. Genes Chromosomes Cancer 19:192-194

33. Talerman A (1972) A mixed germ cell-sex cord stroma tumor of the ovary in a normal female infant. Obstet Gynecol 40:473-478

34. Talerman A (1972) A distinctive gonadal neoplasm related to gonadoblastoma. Cancer 30:12191294

35. Talerman A, van der Harten JJ (1977) Mixed germ cell-sex cord stromal tumor of the ovary associated with isosexual precocious puberty in a normal girl. Cancer 40:889-894

36. 36. Talennan A (1979) Gonadal tumours composed of germ cells and sex cord stroma derivatives. Patol Pol 30:22 1-228

37. Talerman A (1980) The pathology of gonadal neoplasms composed of germ cells and sex cord stroma derivatives. Pathol Res Pract 170:24-38

38. Tavassoli FA (1983) A combined germ cell-gonadal stromal-epithelial tumor of the ovary. Am J Surg Pathol 7:73-84

39. Tian Q, Frierson HF, Krystal DW, Moskaluk CA (1999) Activating c-kit gene mutations in human germ cell tumors. Am J Pathol 154:1643-1647

40. Tickoo SK, Hutchinson B, Bacik J, Mazumdar M, Motzer RJ, Bajorin DF, Bosl GJ, Reuter VE (2002) Testicular seminoma: A clinicopathologic and immunohistochemical study of 105 cases with special reference to seminomas with atypical features. mt j Surg Pathol 10:23-32

41. Tokuoka S, Aoki Y, Hayashi Y, Yokoyama T, Ishii T (1985) A mixed germ cell sex cord stromal tumor of the ovary with retiform tubular structure: a case report. Int J Gynecol Pathol 4: 16 1-170

42. True LD, Otis CN, Delprado W, Scully RE, Rosai J (1988) Spermatocytic seminoma of testis with sarcomatous transformation. A report of five cases. Am J Surg Pathol 12:75-82

43. Ulbright TM, Srigley JR, Reuter yE, Wojno K, Roth LM, Young RH (2000) Sex cord stromal tumor of the testis with entrapped germ cells. A lesion mimicking unclassified mixed germ cellsex cord stromal tumor. Am J Surg Pathol 24:535-542

44. Ulbright TM (2005) Germ cell tumors of the gonads: a selective review emphasizing problems in differential diagnosis, newly appreciated, and controversial issues. Mod Pathol 1 8(Suppl 2): S61S79

45. Young RH, Dickersin GR, Scully RE (1983) A distinctive ovarian sex cord stromal tumor causing sexual precocity in the Peutz Jeghers syndrome. Am J Surg Pathol 7:233-243

46. Young RH (2005) Sex cord-stromal tumors of the ovary and testis: their similarities and differences with consideration of selected problems. Mod Pathol 18:S81-S98

47. Zuntova A, Motlik K, Horejsi J, Eckschlager T (1992) Mixed germ cell-sex cord stromal tumor with heterologous structures. Int J Gynecol Pathol 11:227-233

This is the author's final version of the article, prior to publication in Virchows Arch (2006) 448: 612-622.

C) Springer-Verlag 2006. The published version is available at http://dx.doi.org/10.1007/s00428-006-0155-z, or via www.springerlink.com. 


\section{TABLES \& FIGURES}

Table 1 PCR primers used in the study

\begin{tabular}{|l|l|l|l|l|}
\hline Gene/exons & & Name & & Primers \\
\hline c-kit exon 9aa & & $\begin{array}{l}\text { c-kit e9aNF } \\
\text { c-kit e9aNR }\end{array}$ & & $\begin{array}{l}\text { GAGTAAGCCAGGGCTTTTGTT } \\
\text { CGTGCCATTGTGCTTGAAT }\end{array}$ \\
\hline c-kit exon 9bb & & $\begin{array}{l}\text { c-kit e9bNF } \\
\text { c-kit e9bNR }\end{array}$ & & $\begin{array}{l}\text { CCGTTTGGAAAGCTAGTGGT } \\
\text { CAGAGCCTAAACATCCCCTTA }\end{array}$ \\
\hline c-kit exon 11 & & $\begin{array}{l}\text { c-kit el iF } \\
\text { c-kit el 1 } \mathrm{R}\end{array}$ & & $\begin{array}{l}\text { CTATTTTCCCTTTCTCCC } \\
\text { TACCCAAAAAGGTGACATGG }\end{array}$ \\
\hline c-kit exon 13 & & $\begin{array}{l}\text { c-kit el3F } \\
\text { c-kit el3R }\end{array}$ & & $\begin{array}{l}\text { CATGCGCTTGACATCAGTTT } \\
\text { CAATAAAAGGCAGCTTGGACA }\end{array}$ \\
\hline c-kit exon 17 & & $\begin{array}{l}\text { c-kit el 7F } \\
\text { c-kit el7R }\end{array}$ & & $\begin{array}{l}\text { GGTTTCTTTTCTCCTCCAACC } \\
\text { TGCAGGACTGTCAAGCAGAG }\end{array}$ \\
\hline PDGFRA exon 12 & & $\begin{array}{l}\text { PDG el2F } \\
\text { PDG E12R }\end{array}$ & & $\begin{array}{l}\text { CTCTGGTGCACTGGGACTTT } \\
\text { GGAGGTTACCCCATGGAACT }\end{array}$ \\
\hline PDGFRA exon 18 & & $\begin{array}{l}\text { PDG el8F } \\
\text { PDG el8R }\end{array}$ & & $\begin{array}{l}\text { GCTACAGATGGCTTGATCCTG } \\
\text { GACCAGTGAGGGAAGTGAGG }\end{array}$ \\
\hline
\end{tabular}

${ }^{\mathrm{a}} 5$ ' end of exon 9

$\mathrm{b}_{3}$ ' end of exon 9

Table 2 Immunohistochemical results

\begin{tabular}{|l|l|l|l|l|l|l|l|}
\hline $\begin{array}{l}\text { Case } \\
\text { antibodies }\end{array}$ & $\begin{array}{l}\text { Case 1 } \\
\text { (testicular) }\end{array}$ & $\begin{array}{l}\text { Case 2 } \\
\text { (testicular) }\end{array}$ & $\begin{array}{l}\text { Case 3 } \\
\text { (testicular) }\end{array}$ & $\begin{array}{l}\text { Case 4 } \\
\text { (ovarian) }\end{array}$ & $\begin{array}{l}\text { Case 5 } \\
\text { (ovarian) }\end{array}$ & $\begin{array}{l}\text { Case 6 } \\
\text { (ovarian) }\end{array}$ & $\begin{array}{l}\text { Case 7 } \\
\text { (ovarian) }\end{array}$ \\
\hline NSE & Neg & Neg & Neg & GC+ SCC- & GC+ SCC- & GC+ SCC- & GC+ SCC- \\
\hline PLAP & Neg & Neg & Neg & GC+ SCC- & GC+ SCC- & GC+ SCC- & GC+ SCC- \\
\hline OCT4 & Neg & Neg & Neg & GC+ SCC- & GC+ SCC- & GC+ SCC- & GC+ SCC- \\
\hline $\begin{array}{l}\text { c-kit } \\
\text { protein }\end{array}$ & Neg & Neg & Neg & GC+ SCC- & GC+ SCC- & GC+ SCC- & Neg \\
\hline AE1-AE3 & GC+ SCC- & Neg & Neg & SCC+ GC- & GC+ SCC- & SCC+ GC- & SCC+ GC- \\
\hline CAM 5.2 & Neg & Neg & Neg & Neg & Neg & Neg & Neg \\
\hline EMA & Neg & Neg & Neg & Neg & Neg & Neg & Neg \\
\hline CD3O & Neg & Neg & Neg & Neg & Neg & Neg & Neg \\
\hline Inhibin & SCC+ GC- & SCC+ GC- & Neg & SCC+ GC- & SCC+ GC- & SCC+ GC- & SCC+ GC- \\
\hline ASMA & Neg & Neg & Neg & Neg & Neg & Neg & Neg \\
\hline
\end{tabular}

Neg Negative, ASMA $\alpha$-smooth muscle actin, FLAP placental alkaline phosphatase, EMA epithelial membrane antigen, $G C$ germ cells, $S C C$ sex cord stromal component

This is the author's final version of the article, prior to publication in Virchows Arch (2006) 448: 612-622.

C) Springer-Verlag 2006. The published version is available at http://dx.doi.org/10.1007/s00428-006-0155-z, or via www.springerlink.com. 
Table 3 Molecular cytogenetics results

\begin{tabular}{|l|l|l|}
\hline Case number & 12p:CEP 12 ratio & Result \\
\hline 1 & 1.15 & \\
\hline 2 & AF & AF \\
\hline 3 & NA & NA \\
\hline 4 & 1.14 & - \\
\hline 5 & 1.15 & - \\
\hline 6 & AF & AF \\
\hline 7 & 1.59 & + \\
\hline
\end{tabular}

$A F$ Analysis failed, $N A$ not available, (+) amplified, (-) not amplified

Fig. 1 Testicular MGSCT showing predominance of spindle cell stromal component in some areas. Hematoxylin and eosin staining

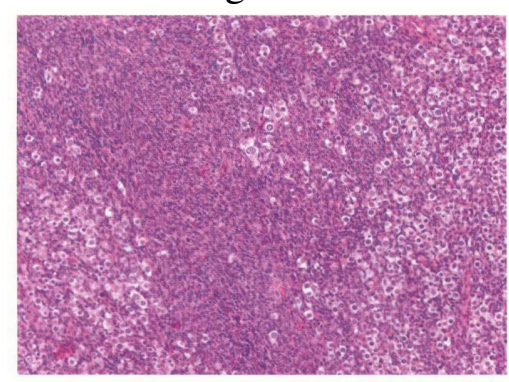

Fig. 2 Testicular MGSCT showing that the germ cells often varied in size, ranging from small deeply basophilic cells to large blastic cells. Hematoxylin and eosin staining

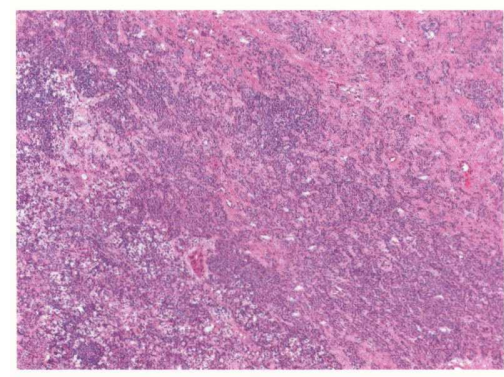

This is the author's final version of the article, prior to publication in Virchows Arch (2006) 448: 612-622.

C) Springer-Verlag 2006. The published version is available at http://dx.doi.org/10.1007/s00428-006-0155-z, or via www.springerlink.com. 
Fig. 3 Testicular MGSCT showing at low magnification that the germ cells form an integral part of the neoplasm and that they do not represent entrapped nonneoplastic germ cells in testicular tubules. Hematoxylin and eosin staining

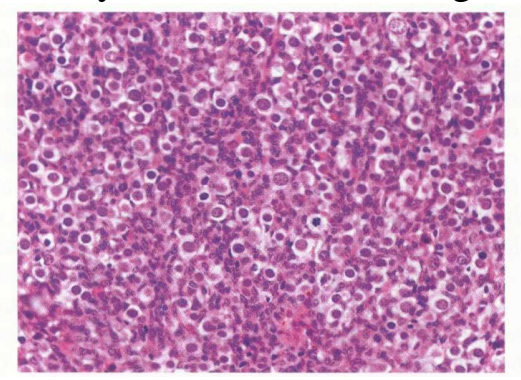

Fig. 4 Testicular MGSCT. Atypical mitoses were found in the germ cells. Giemsa staining

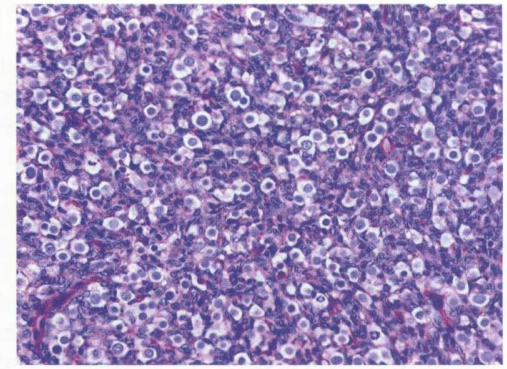

Fig. 5 Testicular MGSCT. A copious amount of cytoplasm and relatively smaller nuclei of the germ cell rendered them a targetoid appearance. The SCC was composed of spindle cells with nuclei having longitudinal clefts and inconspicuous nucleoli. Hematoxylin and eosin staining

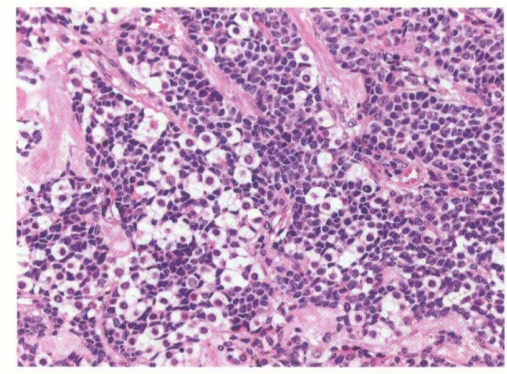

This is the author's final version of the article, prior to publication in Virchows Arch (2006) 448: 612-622.

(C) Springer-Verlag 2006. The published version is available at http://dx.doi.org/10.1007/s00428-006-0155-z, or via www.springerlink.com. 
Fig. 6 Testicular MGSCT. In many areas, the tumor cells were intermixed with dense collagen. Hematoxylin and eosin staining

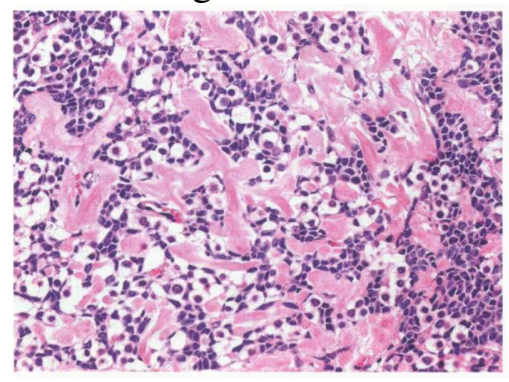

Fig. 7 Testicular MGSCT. Many germ cells reacted positively with the antibody to AE1AE3 revealing a paranuclear dot- or rod-like signal

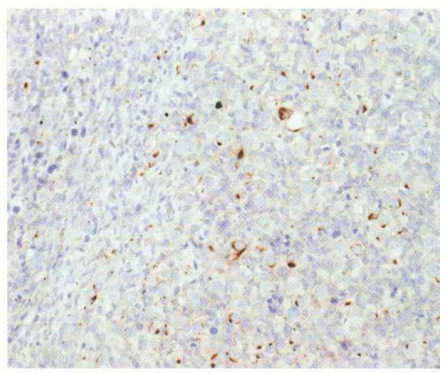

Fig. 8 Testicular MGSCT. In Case 1 as many as $40 \%$ of all germ cells stained with the MIB1 antibody.

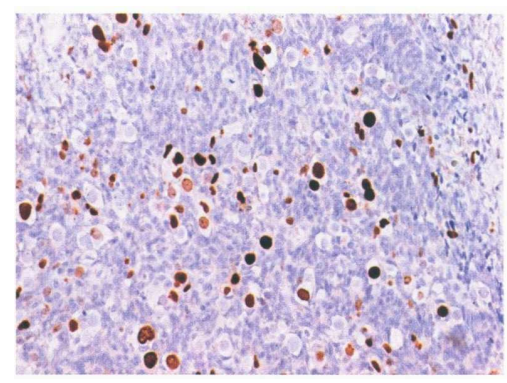

This is the author's final version of the article, prior to publication in Virchows Arch (2006) 448: 612-622.

(C) Springer-Verlag 2006. The published version is available at http://dx.doi.org/10.1007/s00428-006-0155-z, or via www.springerlink.com. 
Fig. 9 Testicular MGSCT. Inhibin stained the sex cord stromal cells

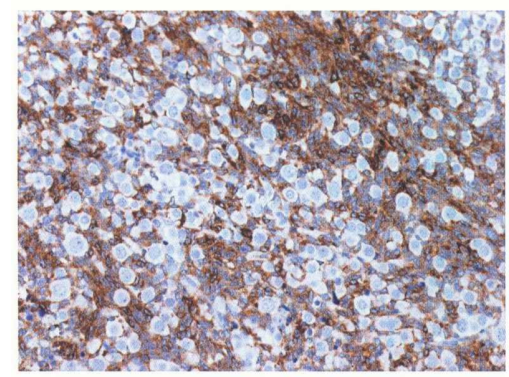

Fig. 10 The germ cells in all four ovarian cases had cytomorphological features identical to those seen in the classical seminomas/ dysgerminomas. The cells possessed the typical "square off" quality of the nuclei. Hematoxylin and eosin staining

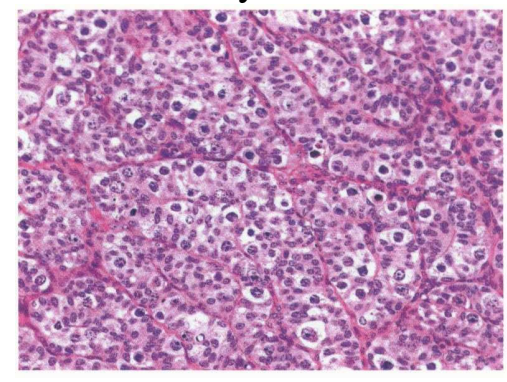

Fig. 11 Ovarian MGSCT. These neoplasms formed a lobular pattern. Sex cord stromal cells formed a peripheral palisading. Hematoxylin and eosin staining

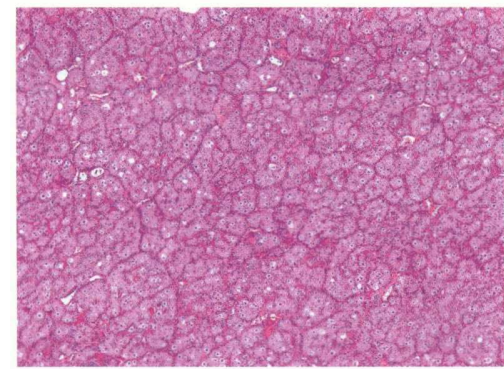

This is the author's final version of the article, prior to publication in Virchows Arch (2006) 448: 612-622.

(C) Springer-Verlag 2006. The published version is available at http://dx.doi.org/10.1007/s00428-006-0155-z, or via www.springerlink.com. 
Fig. 12 Ovarian MGSCT. One ovarian tumor showed a vague similarity to sex cord tumor with annular tubules. Hematoxylin and eosin staining

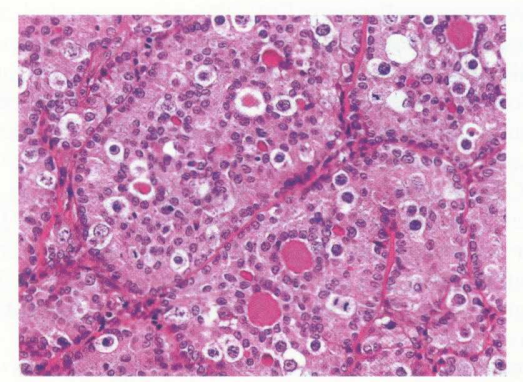

Fig. 13 Ovarian MGSCT. In one case (Case 6), the sex cord stromal cells differentiated into a columnar glandular epithelium with a ciliated brush border. Hematoxylin and eosin staining

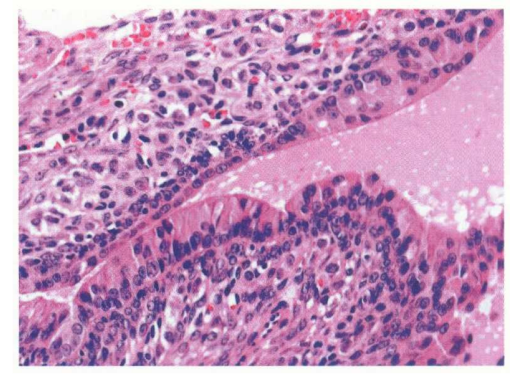

Fig. 14 Ovarian MGSCT. The SCC in Case 5 differed from the other three ovarian cases in that it formed trabeculae with sex cord stromal cells lying perpendicular to the long axis of the trabeculae. Hematoxylin and eosin staining

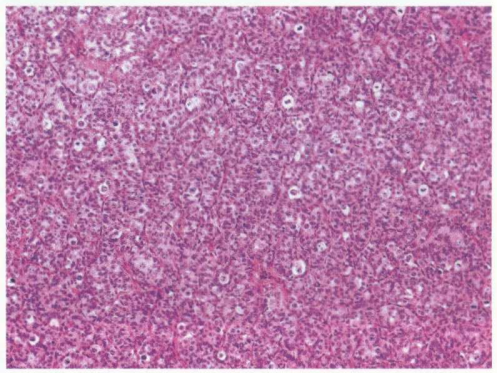

This is the author's final version of the article, prior to publication in Virchows Arch (2006) 448: 612-622.

(C) Springer-Verlag 2006. The published version is available at http://dx.doi.org/10.1007/s00428-006-0155-Z, or via www.springerlink.com. 
Fig. 15 Ovarian MGSCT. The germ cells and SCC formed sharply circumscribed lobules. In no case in our series did the germ cells grow outside borders of these lobules. The germ cells in this Case 5 stained strongly with the antibody to placental alkaline phosphatase

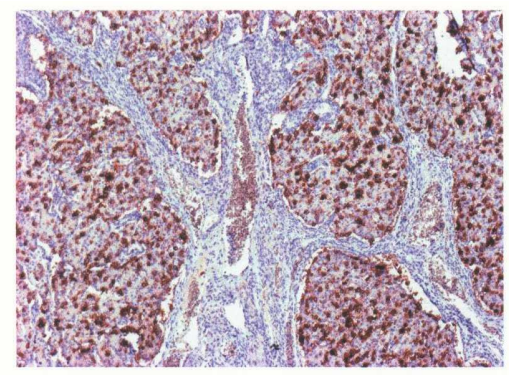

Fig. 16 Ovarian MGSCT. FISH analysis using 12p (Spectrum Green) and CEP 12 (Spectrum Orange) probe. Visualization under Dual Band Pass filter, a Case 5- nonamplified two green (12p) and two red (CEP 12) signals are presented in the nuclei. b Case 7- amplified five green (12p) and two red (CEP 12) signals are presented in the nuclei
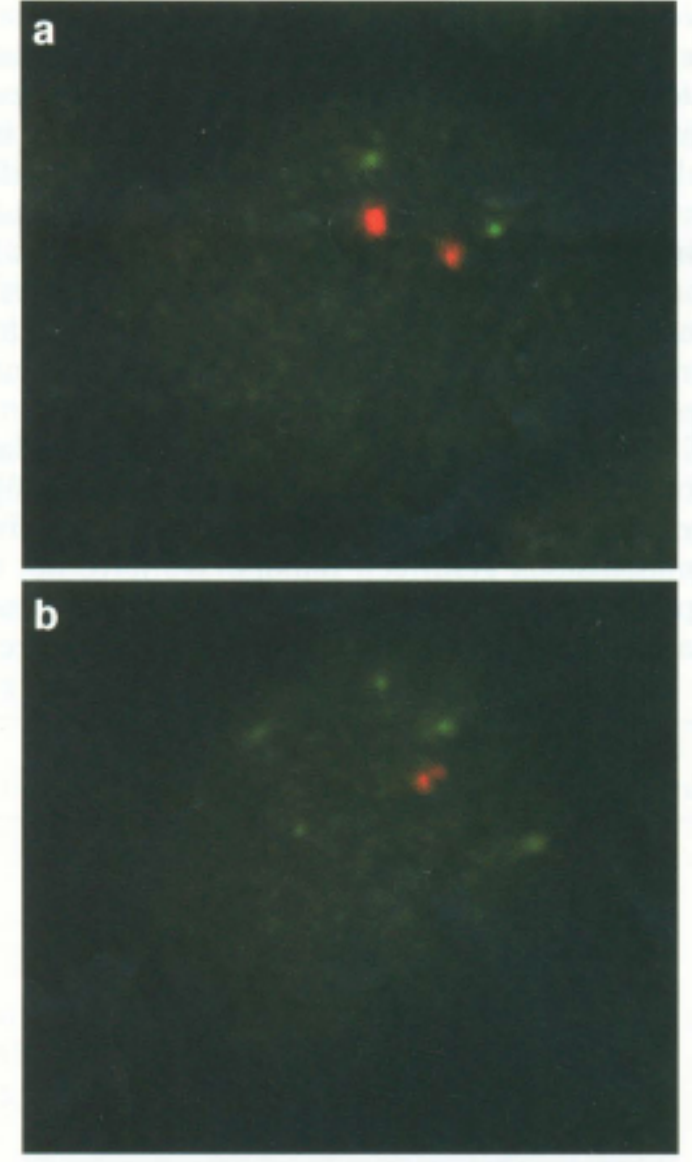

This is the author's final version of the article, prior to publication in Virchows Arch (2006) 448: 612-622.

(C) Springer-Verlag 2006. The published version is available at http://dx.doi.org/10.1007/s00428-006-0155-z, or via www.springerlink.com. 